Gilbert $\boldsymbol{s}$ George. The Singing Scuipture, 1973. Art Gallery of New South Wales, 5 ydney. Photo, Collection John Kaldor Archive.

\title{
Missing in Action
}

Gilbert \& George's and Marina Abramovic/Ulay's actions of the 19705 were collaborations that blurred and doubled the "normal" figure of the artist as an individual body. This type of collaboration had the properties of a third identity, but did the new identity resemble a third hand, a doppelganger (an apparition associated with death, sometimes experienced historically as a shadow or as the double of a living person), or a phantom extension of the artists" joint will, rather like a phantom limb? The nature of this modified artist is important, for it represents a strategy to convince the audience of new understandings of artistic identity. In this regard, these 1970 actions now seem absolutely presclent with respect to art in the late

Charles Green

\section{Doppelgangers and the} Third Force: The Artistic Collaborations of
Gilbert \& George and
Marina Abramovic/Ulay

1. See Mchael Fried's arguments in Absorposn and Theosicaltr: Atinting and Behalder in the Are of Dideros (Berkeley: University of Calfornis Press 1960): new ed. Ohicago: Uhivenity of Chickest Press. 1988, I have extensively drawn form his nnefil glass of that bock in the impoductary thap. ter of his Coubet i Reotim (Chicase: Uriventity of Chicage Press 1990). My next paragrapho-and al the imblict rethearsak of absarpoion and the atricalty rely herely on frieds teect. for a dis. cussion and critical evd uation of Midsoel Fried: laser writine placing his didectic of abocorptian and thearrical icy into a critical, posomodern con teet, set Stephen Melvile. "Compeling, Acts, Haunting Comections" in Seoms Art os a Phlosophical Concext (Amroterdam: Gondon + Bread Arts, 1996], 187-98. Metwik conwincingty points out that Fried's binary construction is inad equate though usefl for, in art. the terms of the atricalty and visulity overisp (191)

2. Deris Diderot, Oidersc on Art-Valume One:

The Solan of $1765^{\circ}$ and "Notes on Paroing" and

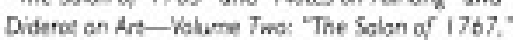
ad. and crars. jath Goodruas (Nwew Haven: Yase University Press, 1995); for a review of this oranalation, see P. N. Furtark. Styllst at the Solon: The Impetuous flood of Diderots Art Crividism, Tirn Literary Subplement, Narember 10, 1995

4.5.

3. Fried, Coubet is Redim, 276.

4. Ibid., 7 . one clear artistic precedent from a much earlier period-the Enlightenment. It had been theorized, for example, in a completely different context, that of Denis Diderot's 1767 essays on the landscape painter Claude-Joseph Vernet. ${ }^{1}$ In his celebrated "Salon" of 1767 . Didernt imagined himself stepping into and taking country walks in Vernet's landscapes. To recapitulate Fried's elaborations of Diderot's theories, this imagining was prompted by Diderox's proposal that the spectator of a painting must be free and active, not just a passive consumer, and conversely that the painting itself should seem to be an impassive object in nature and not appear to be asking to be looked at. Diderot was arguing for two ideas: The beholder has an active place and role in the work of art, and the work of art can be a place in which the artist or the viewer could "go for a walk" and mentally move around within the picture-space. The resulting artistic preference for the painter's self-effacement and depersonalization represented a departure from previous Rococo ideas of theatrical self-presentation and the spectator's appreciation of such theatricality. Mental travel was part of the process of dissociation in a special case of absorption-the pastoral-in which the disembodied spectator became a visually active phantom participant in the work itself.

Fried's reading of Diderot provides a conceptual model for understanding artistic self-representation in which the attributes of a declamatory, assertive artistic self are apparently absent. ${ }^{3}$ Acoording to Fried, the risk of the overtly theatrical was the fallure to convince the beholder of the reality of the illusion presented on the pictorial surface. ${ }^{+}$The element of theater, though, could be systematically negated through the means of the representation of profound 


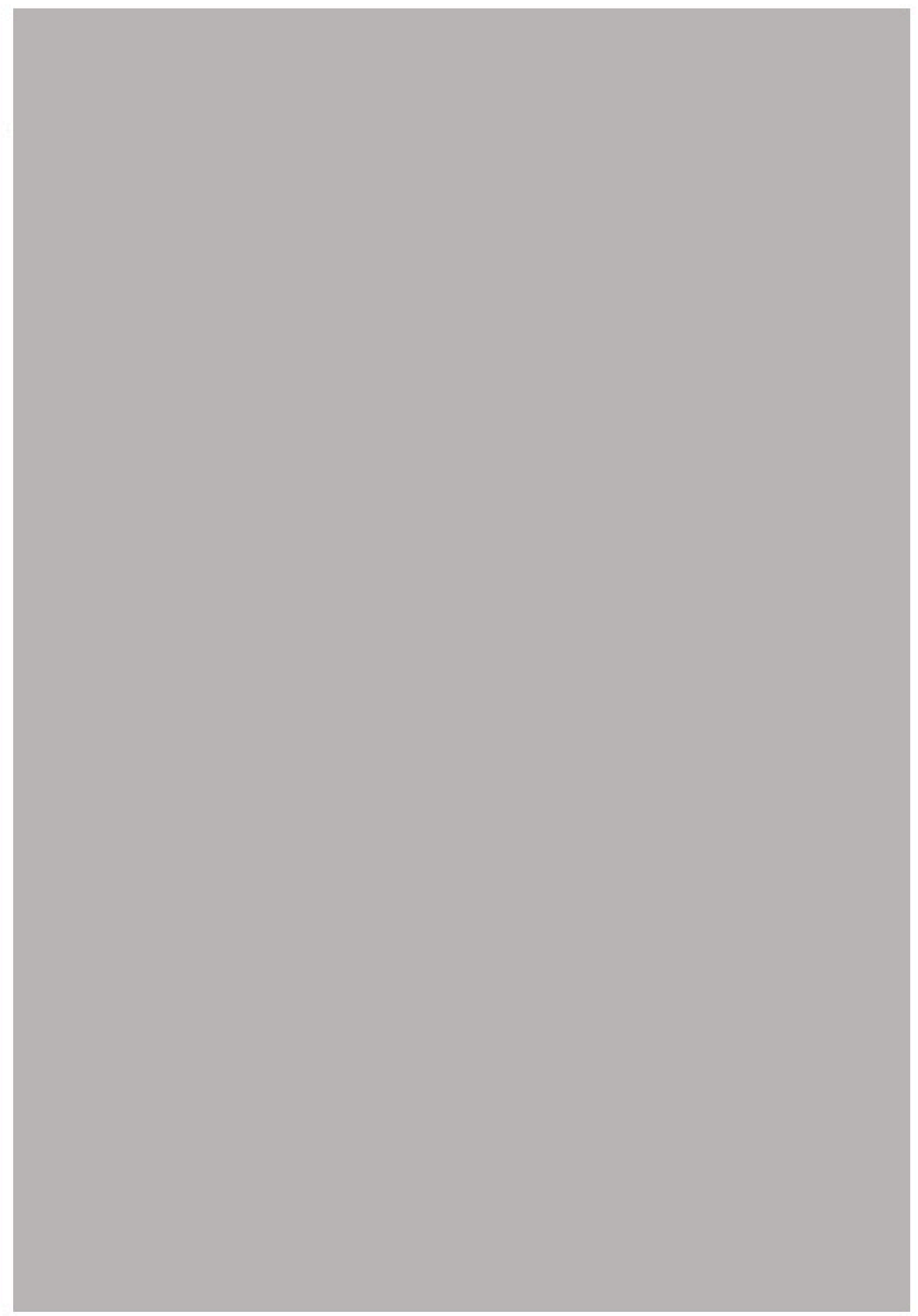

3 sUMmsk laos 
5. My misuse of Fried's arsuments to dexcribe exampies of an art form that he desested is far form urprecederted. lack Burrharn observed that his "continuous and perpetusi present" was, if the formolist had the eyes to see it. exactly the some qual iry experienced in the expanded faild of pont. object rival-baved arti vee Burnhwis chapter "Otiects und Ricuat Tawieds a Working Ontology of Art," in Great Westem Sat Works: Essoys on the Meaning of Prot-formolst Art (NNew York: George Braziler. 1974). 152. 6 See Glbert 3 Ceerze. A Mensage form the Scupton. Aupust 1969, poveal sculperne. The teat is quoted in Michael Morrihan, "Gilbert 3 Gearge," Soddo insemoriand, I79, na. 922 (Ma) $197010196-197,196$.

7. Ibid. 196.

8. See Carter Rateift, 'Glbert \& Gesrase The Fubric of Ther Words" in Gloert 8 Gearze. The Sirgige Selpoune (Naw York: Anthany McCalt, 1993), 35. self-absorpeion. ${ }^{5}$ Marina Abramovic/Ulay's Relubisn Wows (1976-80) and Nightsou Crosing $(198 \mathrm{r}-8 \mathrm{3})$ crossed the limits of normal sensation and the boundaries of gender into unrepresentable experiences of which the index was the enactment and presentation of extreme self-absorption. Both teams re-created themselves as distant, spectralized apparitions in which a doppelganger-a third, phantom identity created by team effort-obscured the individual artists. These recreations were uncanny, marked by rhythmically disjointed movements and the stillness of marionettes or mimes.

\section{Gilbert \& George}

Gilber \& George first exhibited The Singing Sculpture in 1969 at the Royal College of Art in London as Our New Sculpture and, shortly after, at St. Martin's School of Art under the present title. The two "sculprors" stcood on a small table in drab suits, their faces and hands covered in bronze paint, and sang the English music-hall standard "Underneath the Arches" to a long-playing record acoompaniment. Each time the record finished, one of the artists climbed down from the table, restarted the music, took a walking stick, and handed a glove to the other. The works were long and arduous: five seven-hour days in London in 1970 and ten five-hours days at Sonnabend in New York in 1971 . The two artists had cast themselves both as bomeless aesthetes and as a hybrid work of art composed, in equal portions, of music-hall tramp and Walter Pater. Both identities proposed interminable journeying: As tramps, the artists were doomed to life outdoors on the road or "underneath the arches," just as Pater's melancholic aestheties had suggested a long mental quest for quality.

In August 1969. Gilbert \& George sent an omate manifesto to leading an figures in which they declared that they were "walking along a new road. They left their little studio with all the tools and brushes, taking with them only some music, gentle smiles on their faces and the most serious intentions in the world." In the May 1970 issue of Stodio International, the critic Michacl Moynthan noted this detachment from normal routines, observing that "they appear to be living on private means and Mrs Passmore's [George's wife and mother of his then-sixteen-month-old daughter] eamings as a kindergarten teacher. 'Whatever else they are, they are emphatically not phoneys,' observed Mr Kustow."

Over the next four years, Gilbert \& George re-presented The Singing Sculpture approximately two dozen times, until the August 1973 Australian performances. after which they retired the piece (apart from its brief resuscitation at Sonnabend in (991)." In these performances, although they occupied the same physi cal space as andience members, they stood above them; indeed, they behaved as if they lived on an elevated mental plane, distant from the emotions and cares of ordinary mortals. This strategy was not shared by most performance artists of the period, who strove to bridge the gap between artist and audience. Gilbert \& George had no such desire, and wished to discance themselves entircly from the genre of performance. According to Glbert, "We never did performance, ever. We never called it performance, ever. We didn't like it. For many, many years, we wouldn't even show in the standard group shows to do with performance, because we felt it was something completely different." " In interviews and in correspondence, they absolutely insisted on this difference, dis- 
9. Glbert, in Michele Helmrich, "Gibert s George Interviewed." Eyelve (Brisbane), no. 24 (Antumn-Winter 1994): 16

10 See Ratriff, 35

11. Maymihan, 196

12. For an analysix of mime, we Brian Massurri,

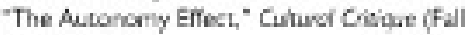

1995): B3-109.

13. Mopnhan, 196. tancing themselves from the interactive connctations of performance art made by charismatic personalities who emphasized bodily experience.

Given this distaste, and in order for their distance to be properly convineing, Gilbert \& George had to eliminate all signs of private personality, preserv. ing only their public personae as artists. They protected their elaborately dignified mental distance as living sculptures both in performance and in private. Working as a collaborative team was one means to this end; refusing to live outside art was another. At a more general level, the detached homelessness of the living sculptures was a literal enactment of the consequences of avantgarde stylistic exhaustion, marking out their distance from both late modernist formalism and Conceptual art alike. ${ }^{\circ}$

As many of their hosts and guides recalled, the two living sculpnures behaved formally at all times, exaggerating genteel etiquette until it became a regal distance. The requirements of detachment meant that they never established eye contact with audiences, nor did they allow time to stop for breaks or to chat between performances. Accosted by members of the crowd during rock concert performances at the London Lyceum in 1969, and by bemused members of The Who at the Sussex Festival that same year, they replied neither to provocations nor to friendly questions off-stage." Their starus as living sculptures, certified by their mask-like face paint (it was, incidentally, reported that they removed this substance from their faces with A,ax, a bighly abrasive kitchen cleanser), prohibited all interaction.

Gilbert \& George's robotic self-control and evasion of personal contact was redolent of the utter self-absorption of mimes. Indeed, their metallic face puint strongly recalled the makeup of these performers, and most English and Australian gallery audiences of the late 1960 s and early 1970 would bave been aware of and might have associated The Singing Sculpture with the thenfamous French mime Marcel Marceau in particular. Gilbert \& George combined Marceau's inscrutability and beavy makeup with his Pierrot-like pathos and aura of vulnerable naiveté. But the link with mime was even more significant than this simple correspondence might suggest, for the affective power of works like The Singing Sculpeure was directly comparable to mime: the removal of speech, except as karaoke-like acompaniment to prerecorded music, and immobility punctuated by jerky movement. ${ }^{12}$

In "The Autonomy of Affect," Brian Massumi eloquently locates mime's power in interruption, and in its decomposition of movement into a series of submovements punctuated by jerks, At each jerk, according to Massumi, drawing on Gilles Deleuze, continuity is suspended. This allows the signification of potential movements that are made present without being actualized, Each jerk is therefore a point at which an instant of virtuality appears. In 1970 , Moynihan described Gllbert \& George moving jerkily like robots on a small table to the strains of "Underneath the Arches." Regarding this motion, George commented, "you know when you're walking and you suddenly feel there's someone you know coming up behind you and your leg and arm and body muscles go stiff with nerves? That's how we walked, completely unrelaxed, a zombie-like walk."is Through this zombie-like motion, Gilbert \& George brought their self-creation- the double ideatity of the collaborationto a scmi-autonomous marionette-like "life." If the discipline of mime has 
14. Sreve Tilis, Touronds on Aerghed of of the Ruppet: Puppety of o Theodical Art (New York: Comtributions in Drams and Thestre Studes. $19923,64-65$

15. bid 64 .

16. Rsitiff, 14,

17. Atramevic: 'In every teil of aur bodf we have anergy that we newer use. Survival situations give you the energy to use this erergy- The satre energy is used by Tibecans in lener Hear exarcises. We netded that excess ervergy when we mast the wark with the bow and arrow pointing at my heart" (Abramoric, belephore carwersutian with

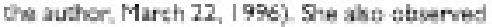
duen 'The perfermance is an exationge of energr' (Abramevie, "Perferming Bodx " Sarny Holl Theatre, Melbourne, April 15, 1998, author's netes). Other eolaborations waren equally awar of the ervaticn of an authorial tharacter toceteding the sum of two idemtitec Afcord ng to Kemar and Malverid, whe had ealaboratively erelved a mytrid kistary painting from a cembiratien of Scoialst Realsm and moderrism during the 19704, "We imenced that dind parvon, the thind artit, buc we never specricaly named thar thind artic." (Alexander Melowid, Laped interview with the author, New York, December 4, 1996; Melanid ciad exteraive Russian literary procedorcs for the renuncision of one's gan voice in favor of an imenced, fcritious idencty, observing, "The artist 'neme" is imporcanc, and is a ficticnal dervick." However, the kencey of artia and artwork hud resulted in a ditereme tope of colaboration. 18. Ulay, quoted in jenvifer Pripos, "Marina Abramowic/Uay/Ulay/Marina Abramovic," Art in Fext, no. 3 (spring 1981): 50. The fame of Zen in the West has mesnc that when art-crivical com. parisons and analogies are made wot Buddhism. they are invariably made with Zen, which was orly one of many schools within the vast heritage of Budd-ist philosophy Abremovic/Llusy's perfonmsnce works were unsysematic secular attempts to explare extreme rates of consciousness. which had been sysermaticaly codifed in Mahapas Buddtism by the "Skx Topics"; see a famous Mahayans mediation morual writuen by Tibetan teacher and mork. \%Gampopa IsGumpopa. The jewed Amament of Liberotian. trans and arnocated by Hettert Guenther [London: Pider. 1959], wil) The Sox Topics were mediation vechniques taugetc by Tlops ialso known as Tilipal the great Budchint myetic and teacher, which induded mediration developing the mystic "irrer hest" or conceneratian the experi-

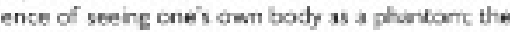
experience of the stite of dreams; the experience of the Radant Light, the experience of the state berween birth and rebirth while living: and the practice of spintual med tstion to rase the con. socusness to higher planes

19. Atringvic/Uay, in Pripas of

20, See "Emptiness: The Two Truths. Eeserpts from 'An Imerview with the Dilvi Lama" SNew York john F. Avedon, 1979, reprinted in Sredelik van Abbemuseum, Uloy \& Morno Abromouc. Modve Wrend Werks 1980-1985, exh cox findhover

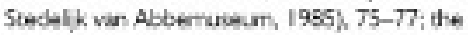
rosts debt to Budthis philoricptiry-and ALramovic's debt in particuiar - 6 acknowiedged certain characteristics of communicative emptiness and awkwardmess, as Massumi has noted, then the marionette has others. According to Steve Tills, a marionette inspires double vision: The puppet-figure is an object, but one onto which the viewer projects hls or ber own emotions and expectations of presence. ${ }^{4}$ Furthermore, the viewer is unable to resolve the confict of seeing the puppet as an object and as a live, sentient subject. " Gilbert \& George embodied a particular doubleness - both literal and as marionettes - for they objectified themselves to the point that they appeared as a pair of emotionless puppets.

There was something else, though, as well: from an initlally ironic, fictive, and performative gesture - naming themselves "living sculptures"- hhey had created a surplus of aura around a single persona. That was the initial doable irony in Gilbert \& George's work from which utter seriousness, without irony, then followed: There was to be no time out." ${ }^{16}$ This is a crucial point. An initlal performative gesture by artists-naming themselves an artistic collaborationcreated an excess of artistic identity that was manifested in the auratic and often fictive presence: the persona of the collaborative tearn, not the diminished person related to the self-objectification of real bodies which had became marionette. The identification of artists with their works, as well as with work isself, was crucial and deliberate: if the artists were deliberately uncommunicative, $\$$ would be the works.

\section{Marina Abramovic/Ulay}

Another entity therefore emerges: collaboration could create a third hand-the authorial excess of an invisible actor. Marina Abramovic/Ulay called this third hand "REST ENERGY," and Abramovic insisted that a third hermaphroditic force, independent of them, was created by collaboration." Abramovic/Ulay"s performances were hard work-labor that, they hoped, would liberate them from the encumbrance of the limits of language. In their trance-like performance Nightsee Cressing, the title of which refers to the soul's spiritual journey. specch was unthinkable. In this work, Abramovic/Ulay dressed in contrasting red and black outfits and sat completely still at etther end of a long table, staring at each other for seven-hour instaliments, often stretching for days. In the 1981 Sydney performance, gold nuggets, a gold boomerang, and a llve diamond python rested on the table. The python in Gold Found by the Artists symbolized the current of psychic energy running down every person's spinal column, traditionally represented, in a wide range of mystical literature, by a coiled snake. This mystical "snake" would, in turn, be awakened by spiritual exercises on which Abramovic/Ulay's focused silences and mental witbdrawal were clearly borrowed. The still-life arrangement of gold and snake on the table somewhat unsubtly prompted the audience to recognize the performance as a tableau vivant in which a process of active but hermetic mental transformation was taking place. The alchemical stage props "explained" the otherwise completely inaccessible, sealed-aff process performed by the artist-actors. Presumably, the live snake's mobility also indexed their psychic awakening.

In preparation for this performance, Abramovid/Ulay undertook a journey through the most remote regions of Central Australia between October $198 \circ$ and March 1981, during the course of which they experienced a variety of harrowing physical and mental exercises. As Ulay has stated, "I think our 


\section{Marina AbaramoviciUlay. \\ Gold Found by the \\ Artatsinightsed Crossing. \\ 1981. Art Gallery of New \\ South Wales, Sydney. \\ Photo, Collection Art \\ Gallery of New South \\ Wales.}

in this interview. To understand the concept of erponess aluded to by the artists, it is necessary to reier to the Mahapena Buddhist uncerstanding of the "bedrock" underlying individual paycholos. cal ife and therefione to al hide to the concept of "5landiss" exdared in 36 ampopa. 200. The Skand-as are the frev counthents of inchidus prochalcestal bif- the Budithist description of mind - which cengists of corporeality, feelng, sensation/idertification, motvation, and consciousness. Mahsrama Budtism teaches that these constituents are tozesher an scourate description of the reind, but that they do not begn to describe anything that bs ulimate. The mind is provisional. and so are the fruits of artalysis, In the some wor the experiences of medication (and, presumably. centemglative performante attivity) that $\mathrm{gr}$ beyand the waverine torfused nature of normal. mental artivity are nothing utimate in themsehes desert trip was part of tuning yourself more, training yourself." mad, Broce Chatwin-like epic of crushing summer heal, loneliness, disappointment, and eventual epiphany took them to Papunya, near Alice Springs, and then through the Gibson Desent to Leonora, Willuma, and Mount Newman. Much of their journey was spent struggling with sheer physical discomfort while camping alone for extended periods at remote desert waterholes. In a brief interview, published shortly after they had returned from the desert, Abramovic/Ulay recorded their frustrated expectations about the apparently inaccessible Other: "I must say for myself 1 expected very much from the contact with Aborigines, and I got very disappointed." $"$ Disappearance, Abramovic noted, described the impermanenoe of both her performances and Aboriginal ceremonies, and each type of disappearance from public view was 2. way of gathering psychic power.

Abramovic/Ulay were also aware of the phillosophical connotations of conceiving emptiness and void as strata underlying phenomenological existence. They even reprinted an interview with the Dalal Lama on this subject in their 1935 exhibition catalogue, Modus Vivendi ${ }^{30}$ According to Abramovic, the intense visions they experiencod during Nightsen Crosing compelled them to seek a way of organizing or controlling the flood of disruptave, powerful sensations. They accordingly visited the large Tibetan Buddhist community at Dharamsala, in 
though at the tive they appes to be. Afteraands. the s.biect can mistabe such memories for the real things themselves. Of clinging to this type of nostalog the subject turns the experience of rapore into the worship of dead concepts, which has the effect of duling and retarding mecitasion. Thus, the acovities of mind are regarded as not only constructed by language. but also as completely liuson for there is only enconess. sGampopa consinues: "Since $\mathrm{k}$ is not obtained by itself, from others or boch/Nor by the three aspects of time [past, present or fuare] /The beief in a Seff colapses" (207). Mortification of the bodf was a stardard tectrique amongst both Buddrist and Hindu mystcs (and sp riasl aspirants generaly). but the demonstration of gres: physical endurance was not an end in itsef; it was the mears to the strpping awsy of layers of mencal activisy. As another importank Budchist sutra observes: "First open this heap of sken with your inselect/Then separate the flesh from the ratwork of bores wth the scapel of discriminating awareness / H Hswire opened the bones also look into the martow/And see for yoursell/Whecher there is anyeting solis" (\$7). Marins Abewrovic' Ulby were effestively carrying on this tradtion whout strict achererce to iny orgarized mystcal system

21. Abrarrovic, telephare cerrwersation with the suther:

22. Maring Abrathovic/Uay, "Interviem," in Nick Waterlow. ed. Europeon Didigut: Biennale of Sochey [Sycter, Ant Gollery of New Soush Wales. 1979). 19.

23. Abramoviculay, in Bojara Pejik, "being hthe Bodf: On the Spiritual in Maring Abramovic's Art, in Fnedrich Messhede, ed. Marno Abromowic (Berin: National Galery and Seuctere. Edition Crac. 1993) 34.

24. Abramovic, Bisgraphy, 35.

25. Abramovic, "Potorming Body."

26. This, as leass, is my recolection of their Australian perfonmances, confirmed by others. indudirg Australizn curater jenrifer Phiping in whese Melbeurre house they staped for several medks upan their reourn from the desert. 27. Gibert, in Hedmnich, "Glbert \& Georze inneviewed." 17 . northern India, where the Dalai Lama resides, and undertook structured Mahayana Buddhist meditation sessions. ${ }^{3}$

Through this process, Abramovic/Ulay were digging through the sediment of culturally constructed gender roles, they thought, to the bedrock beneath and, at the same time, creating a new "body" outside the binary iterations of male/female or nature/culture. During their 1980-8n Australian journey. Ulay stated, it was "not important that we are man and wocnan. We talk of ourselves as bodies." Moreover, from the beginning of the collaboration, they spoke of themselves as parts of a "two-headed body." 23

It is immediately apparent that interpreting this art as symptom is of limited use, for Abramovic/Ulay's affective "REST ENERGY" had to be distinguished from the agency of therapeutic catharsis, even if the processes overlapped to some degree. ${ }^{24}$ Abramovic emphasized that the endurance of pain was irrelevant to her conception of the works" meanings: "Pain is not there in the performance." 25 Collaborative biography was a resource, but it was not regulated by trauma. Their repressions were neither uncovered nor resolved by collaborative catharsis. They were sublimated through a ritualistic, meditative system of repetition, distance, and self-absorption.

In both teams' performances, the artists folded themselves into an elusive extra identity: the double body of the collaborative artist. Gilbert \& George dressed alike and, with metallic facial paint on, looked alike. Abramovic/ Ulay's bodies changed dramatically during their collaboration. According to many observers, they became remarkably similar in appearance, even though they made a work highlighting the differences between their physiques, Commonis Body - Capitaliog Body (1979). In fact, they looked and behaved almost like twins: they were both tall, muscular, athletic, and long-haired and dressed in similar clothes. ${ }^{\text {th }}$ In Relation in Time and Breathing in-Breuthing Out (both 1977), they effectively prescnted themselves as joined halves of a double being, like Siamese twins. In addition, they had met on their mutual birthday. Abramovic/Ulay were well aware that they were re-creating themselves as doubles-that they were moving beyond conventional gender-based markers of identity at the same time that they were attempting to develop faculties such as telepathy through sensitization processes. In public lectures after their collaboration had ended, they described the collaboration as symbiotic, emphasizing the absolute trust that had been necessary to produce their works.

Just as Abramovic/Ulay, through extreme self-absorption, spectralized their bodies, so their collaborative body became their real body, for their corporeal bodies had been stripped of normal significance, like shadows. Their collaborative work implied a phantom body - an apparitional third entity created by the two artists-and the nature of this entity, either in the "safe house" of the art gallery or the world ontside, was uncanny, for the distinction berween the real and the phantasmic was blurred. Their individual identities were marginalized, spectralized, or became progressively and deliberately less accessible. In this, the team's evolution resembled that of Gilbert \& George. Asked why they made a point of not distinguishing their separate contributions to the collaboration, George replied, "Well, it's nos based on that. It is 'us' doing it together." is 
23. Elizabeth Grace, Wabtio Boches: Tormanth a Corpareal feminam (Sycher: Allen and Unwin. 1994). 41-12.

29. Abramovic, welephone carturastien with the author.

30. Pejc, 26

31. See Nathan Katz Trasangz and Deconstruc: tione Tibecan Hertseneutiss and the Yars Controwersy, Phinunghy Esat and Weit 34, no. 2 (Apre 1980): 185-200; we aloo Kevin Hart, The Trespors of the Sign: Deconstruction, Theabeg and Thiosophy ICambridge: Cambridge Universicy Press 1989)
There is a linked proposition - that the body constituted in artistic collaboration was a phantom extension of the artists' joint will, rather like a phantom limb. In Volatile Bddis, Elizabeth Grosz explains the phenomenon of a phantom extension of the will. She suggests that "The pbantom limb is a libidinally invested part of the body phantom, the image or Doppelgangar of the body the subject must develop if it is . . . to take on voluntary action in conceiving of itself as subject. "18 Grosz offers a way of theorizing the collaborative artist formed by the teamwork of two or more artists - the artists' phantom appendage or third hand. Although this is a familiar proposition about collaboration and teamwork, it is more than a poetic metaphor. In the cases of both Gilbert \& George and Abramovic/Ulay, artistic collaboration was an aesthetic gesture born of free choice. It was a way of acting freely rather than capitulating to circumstance, training, or expectations. Perhaps it was also a way of seeing the limits of the artistic self clearly. In the case of artists who were also actors in their works, it was a way of having the artistic self made available for self-scrutiny. Grosz observes that human subjects are never able to see their own bodies completely. While hands and legs may be visible, for example, the small of the back cannot be seen. The out-of-body, synchronistic visions of psychics-who say in trance they see their bodies from above and from several sides at once-sometimes enable a point of view of the whole body. In collaboration, however, the creation of another synthesized subject seems to suggest that the impossible idea of a unified body-image may be almost magically attainable by the con|unction of complementary parts: Abramovic reported that during the extended sllences of Nightsot Crositg. she had the sensation of seeing in every direction around her, as if every pore of her body could see, and of developing a spectacularly magnified, allencompassing sense of smell, 2 ?

Collaboration in which the artists acting out dramas of real communion and pain suggested to many viewers an almost unbearable closeness. However, the poles of schizoid division and fusion were not, as we have seen, the only identities created. In their actions, though, Abramovic/Ulay directly referred to "body memory" and a "third force," as they interacted with each other but ignored their audience. They stoically endured extraordinary self-abuse in their experiments with the paranormal in order to create a new jdentity, their hermaphroditic state of being. These were not straightforward attempts to experience an unmediated state of perception; the recuurse by Abramovic's friend, Bojana Pejic, to a concept of prellngulstic communication obseured the deconstructive nature of this artistic collabozation. ${ }^{30}$ Abramovic herself often hindered this understanding, forher presentation of an eclectic collage of geomancy, Tibetan Buddhism, and Aboriginal shamanism obscured the differences between lifestyle and nigor. The bedrock she referred to was absence-specifically, the concept of absence from Buddhist discussions that refused all talk of essences. Many poststructuralist commentators have noted that systems evoking or citing a ground of emptiness, negation, and voidness are not necessarily utoplan, Jungian, or philosophically naive at all, "Abramovic/Ulay. in particular, acknowledged sopbisticated non-Western quasi-deconstructive precedents in Mahayana Buddhism.

To be sure, ocher artists and writers of the 19606 and 19705 had empha- 
Gilbert \& George. The Singing Sculpture, 1973 . Art Gallery of New South Wales, Sydney. Photo, Collection John Kaldor Arehive. sized the possibilities of active, nonpathological body-image disintegration and reorganization. Influential 196os counter-cultural psychologists such as Richard Alpert and Timothy Leary - who had been significantly influeneed by Tibetan Buddhist psychology, Islamic Sufi dance, Christian mystics such as Nicholas of Cusa, and proto-counter-cultural theorists including Aldous Huxley-had over-romanticized extreme self-alienation, doubling, and depersonalization. And during the same period, Joseph Beuys was actively proselytizing a concept of the artist as a paradigmatic example of actively chosen personal freedom. In these widely circulated terms, collaboration was a way of secing oneself as a nonalienated, free subject, for it was an example of a free action by an individual who had stepped outside the boundaries of personal expertations and conditioning.

\section{The Authorial Excess: Collaboration as a Decision}

The limits of representation are also the limits of language, and what lay beyond these limits had been in itself an important and complex-but heterogencous - concept in other Conceptual art of the period. Gilbert \& George's refusal to take time out to be anything other than living sculptures and Abramovic/Ulay's third source of energy were strategic means of sledding the traditional signs of unwanted artistic personality - the conventional studiobased artistic identity increasingly under question in the 1970 . Such extensjons of Conceptual art were predicated on the disintegration of authorial stability. but even more importantly on something more: the limited horizon of the conoept of identity itself. This artistic authorship identified itself, in Abramovic and Ulay's complex perspective on language, for instance, with an emptiness and blankness that was, the artists were in effect asserting, outside and not inside the horizon of representation. This flight outside the prison-house of language - If it can be fudged to bave been successful-was posslble precisely because of the teams" escape as individual "artists" from their personal bodies into the uncanny realm of phantoms.

Charks Cirren is a bethrte in the Schocl of Art History and Theory at the University of New Scuth Wales. In 1995 he published an introduction to the last twenty-five years of Australian art. Aeripherd Iision.

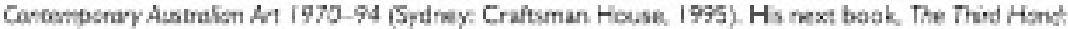

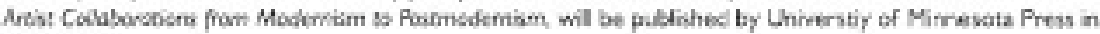
late 2000 .

$4 s$ are journal 


\section{University Library}

\section{- M M N E R VA A gateway to Melbourne's research publications}

Minerva Access is the Institutional Repository of The University of Melbourne

Author/s:

Green, C.

Title:

Doppelgangers and the third force: the artistic collaborations of Gilbert \& George and Marina Abramovic/Ulay

Date:

2000

Citation:

Green, C. (2000). Doppelgangers and the third force: the artistic collaborations of Gillbert \& George and Marina Abramovic/Ulay. Art Journal, 59(2), 36-45.

Publication Status:

Published

Persistent Link:

http://hdl.handle.net/11343/34908 